\title{
Chemical, nutritive, fermentation profile and gas production of citrus pulp silages, alone or combined with maize silage
}

\author{
I. Ülger, S.B. Beyzï, M. Kaliber \& Y. Konca \\ Department of Animal Science, Erciyes University, Kayseri 38039 TURKEY
}

(Received 25 August 2019; Accepted 22 November 2019; First published online 17 March 2020)
Copyright resides with the authors in terms of the Creative Commons Attribution 4.0 South African License. See: http://creativecommons.org/licenses/by/4.0/za
Condition of use: The user may copy, distribute, transmit and adapt the work, but must recognize the authors and the South African Journal of Animal Science.

\begin{abstract}
Quality attributes of citrus pulp silages that were ensiled alone and combined with maize silage were determined. Fresh samples of lemon, orange and tangerine pulps, maize plants and their combinations were fermented in glass jars for 90 days at about $20-25^{\circ} \mathrm{C}$. Treatments included i) $100 \%$ maize silage as control (MS); ii) $100 \%$ lemon pulp silage (LPS); iii) $100 \%$ orange pulp silage (OPS); iv) $100 \%$ tangerine pulp silage (TPS); v) 50\% LPS and 50\% maize silage (LPS + MS); vi) 50\% OPS and 50\% MS; and vii) 50\% TPS and $50 \%$ maize silage (TPS $+\mathrm{MS}$ ). The $\mathrm{pH}$ differed among treatment groups. The highest and lowest $\mathrm{pH}$ values were recorded for MS group and the OPS + MS group, respectively (3.84 vs. 3.51). The highest dry matter (DM), crude fibre (CF), neutral detergent fibre (NDF), acid detergent fibre (ADF) and hemicellulose (HEM) were observed for MS $(P<0.01)$. Citrus pulp silages alone had significantly greater total digestible nutrients (TDN), organic matter (OM) and non-fibre carbohydrate (NFC) values than MS and the combined silages ( $P$ $<0.01)$. Maize silage had higher lactic acid (LA) $(101.2 \mathrm{~g} / \mathrm{kg} \mathrm{DM})$ and acetic acid (AA) (49.3 g/kg DM) concentrations than the citrus groups $(P<0.05)$. In vitro gas production (TG), methane $\left(\mathrm{CH}_{4}\right)$, metabolizable energy (ME) and organic matter digestibility (OMD) of the silages were similar $(P>0.05)$. Thus, citrus pulps can be ensiled in spite of their moisture content. However, to increased DM and nutrient content, the citrus pulps should be ensiled with $50 \%$ maize.
\end{abstract}

Keywords: fermentation metabolites, methane production, organic matter digestibility

\# Corresponding author: sbuyukkilic@erciyes.edu.tr

\section{Introduction}

Citrus is a genus of flowering trees and shrubs including the economically valuable species sour orange, sweet orange, tangerine, grapefruit and lemon. Of these species, orange (Citrus sinensis), tangerine (Citrus reticulata) and lemon (Citrus limon) are commonly grown in Turkey. Low-quality fruits and processing wastes of these fruits may be a significant source of environmental pollution and create serious economic losses. World annual citrus production is about 70 million tons (USDA/FAS, 2003). This quantity is composed mostly of sweet orange (C. sinensis at 67.8\%) (USDA/FAS, 2003), tangerine (C. reticulata at 17.9\%) and lemon (C. limon at 6.3\%) (Kale \& Adsule, 1995). The major citrus-producing countries are the Mediterranean countries of Turkey, Italy, Spain, Greece, Morocco and Egypt (24\%), Brazil (24\%), and the USA (21\%). Pulp is a by-product of facilities that process the fruit into juice. The citrus (orange, tangerine, lemon, grapefruit and orange) production of Turkey was 4769726 tons in 2017 (TUIK, 2017). Despite the studies about ensilage of fruit pulps and potential use of ensiled pulps in animal feeding (Ashbell, 1994; Yalçınkaya et al., 2012; Canbolat et al., 2014; Ülger et al., 2018a) there are large differences between the amounts of fruits used in the fruit juice industry and the amount of pulp released from them (Yalçinkaya et al., 2012). Since some fruits are rich in antioxidants, carotenoids, anthocyanins, pectin, fatty acids, flavonoids, phenolics, vitamins and minerals, which are quite significant for human health and nutrition (Velioglu et al., 1998). Their pulps could be good sources of feed for livestock and their attributes may contribute to silage quality (Ülger et al., 2015; Koc, 2019). Previous studies revealed that these sources reduced feed costs and increased profitability in livestock-raising activities. Such studies also stressed the significance of alternative feed 
sources for livestock. In this sense, fruit pulps are regarded as an important alternative feed source in ruminant nutrition (Filya et al., 2006; Duru \& Kaya, 2015; Ülger et al., 2018b).

The goal of this study was to determine the chemical, nutritional and fermentative values of citrus pulp as a silage material. The characteristics of ensiled citrus pulp were compared with the qualitative parameters of maize silage.

\section{Materials and Methods}

Citrus pulp materials were obtained from a commercial fruit juice factory in Kayseri, Turkey. Citrus pulp DM varied between 201 and $263 \mathrm{~g} / \mathrm{kg}$. Its chemical composition is provided in Table 1. Materials were chopped into $1.5-3 \mathrm{~cm}$ pieces with a silage machine. A total of 42 ( 7 samples $\times 6$ replications) samples [1 maize +3 pulp (lemon, orange and tangerine) +3 mixture (maize + pulps)] were ensilaged in vacuum bags (1 $\mathrm{kg}$ capacity) with a vacuum machine in six replications without treatment. Silage material was filled into bags by hand before the bags were heat-sealed (without melting the plastic bag) and the air evacuated. After sealing, the vacuum machine cut the plastic bag automatically with $5 \mathrm{~mm}$ remaining above the seal. Then, ensiled materials were kept at room temperature (about $20-25^{\circ} \mathrm{C}$ ) for 90 days.

The experimental treatments consisted of i) maize silage (MS); ii) lemon pulp silage (LPS); iii) orange pulp silage (OPS); iv) tangerine pulp silage (TPS); v) lemon pulp silage+maize silage (LPS+MS, 50/50 w/w); vi) orange pulp silage+maize silage (OPS+MS, $50 / 50 \mathrm{w} / \mathrm{w})$; and vii) tangerine pulp silage+maize silage (TPS+MS, 50/50 w/w).

At the end of the 90-day ensilage period, silage samples were taken for chemical and nutritional analyses, which were performed as three replicates. For $\mathrm{pH}$ measurements, $25 \mathrm{~g}$ of silage sample was put in a beaker and $100 \mathrm{~mL}$ distilled water was added. The sample was then mixed in a blender for five minutes, the resultant mixture was filtered through Whatman filter paper, and the $\mathrm{pH}$ of this filtrate was measured (Akyildiz, 1986). Dry matter (AOAC, 2000) (method 934.01), crude ash (CA) (AOAC, 2000) (method 942.05), crude protein (CP) (AOAC, 1996) (method 954.01), crude fibre (CF) (AOAC, 1996) (method 978.10) and ether extract (EE) (AOAC, 2000) (method 920.39) were determined. Neutral detergent fibre was analysed with heat-stable amylase and without $\mathrm{Na}$-sulphite. Acid detergent fibre and acid detergent lignin (ADL) were determined according to the sequential method of Van Soest et al. (1991) with an ANKOM fibre analyser $\left(\right.$ ANKOM $_{220}$ Technology, Macedon, NY, USA) and expressed inclusive of residual ash. Hemicellulose was defined as NDF-ADF.

The Fleig point (FP) was calculated with the equation of FP $=220+(2 \times \mathrm{DM} \%-15)-40 \times \mathrm{pH}$ (Akyildiz, 1986). The total digestible nutrient (TDN) was calculated according to the equation proposed by Chandler (1990), where TDN\% $=105.2-0.68 \times$ NDF\%. The non-fibre carbohydrates (NFC) were calculated with the equation proposed by Weiss et al. (1992): NFC\% $=100-(\mathrm{NDF} \%+\mathrm{CP} \%+\mathrm{EE} \%+\mathrm{CA} \%)$. Total carbohydrates (TC) were determined as: TC\% $=100-(\mathrm{CP} \%+\mathrm{EE} \%+\mathrm{CA} \%)($ Sniffen et al., 1992).

To determine water-soluble carbohydrates (WSC), liquid extractions were prepared with $40 \mathrm{~g}$ silage. Samples were placed in a beaker, and $360 \mathrm{~mL}$ distilled water was added and mixed in a blender. The resultant slurry was filtered through Whatman 54 filter paper and then centrifuged. Supernatant liquid samples were stored at $-20^{\circ} \mathrm{C}$ until analysis. The WSC of samples were determined by the phenol sulphuric acid method (Dubois et al., 1956).

Lactic acid (LA) was determined by the colorimetric method of Barker and Summerson (1941) and by gas chromatography. The volatile fatty acids (VFA): acetic acid (AA, Chem Service O-4), propionic acid (PA, Chem Service O-25) and butyric acid (BA, Chem Service O-5)] were measured with a gas chromatograph (Shimadzu GC-2010+, Kyoto, Japan) with a capillary column $(30 \mathrm{~m} \times 0.25 \mathrm{~mm} \times 0.25 \mu \mathrm{m})$ (Restek, Bellefonte, PA, USA) and with flame ionization detector (FID) over a temperature range of $45-230{ }^{\circ} \mathrm{C}$ (Fussell \& McCalley, 1987).

Citrus pulp that had been milled through a $1 \mathrm{~mm}$ sieve was incubated in vitro in rumen fluid in $100 \mathrm{~mL}$ calibrated glass syringes according to the method described by Menke et al. (1979). Rumen fluid was obtained from a slaughterhouse from two cows that had been fed a diet of at least $60 \%$ roughage (Chaudhry, 2006). Before the rumen fluid was mixed with buffer solution, it was filtered through four layers of cheesecloth under flushing with $\mathrm{CO}_{2}$ and combined with buffer solution in the ratio of 1:2. Approximately $0.200 \mathrm{~g}$ citrus pulp samples were incubated with $30 \mathrm{~mL}$ rumen fluid-buffer mixture in calibrated glass syringes in a water bath at $39^{\circ} \mathrm{C}$. Gas production was determined at 24 hours after incubation and corrected for blank and hay standard (University of Hohenheim, Germany).

Metabolizable energy (MJ kg-1 DM) and OMD of citrus pulp samples were estimated with the equations described by Menke and Steingass (1988):

$$
\begin{gathered}
\mathrm{ME}\left(\mathrm{MJ} \mathrm{kg}{ }^{-1} \mathrm{DM}\right)=2.20+0.136 \mathrm{GP}+0.057 \mathrm{CP} \\
\mathrm{OMD}(\%)=14.88+0.889 \mathrm{GP}+0.45 \mathrm{CP}+0.0651 \times \mathrm{A}
\end{gathered}
$$


Where: GP $=24$ hours net gas production $(\mathrm{ml} / 200 \mathrm{mg})$,

$\mathrm{CP}=$ crude protein $(\%)$,

EE ether extract (\%), and

$A=\operatorname{ash}(\%)$.

Methane was measured with an infrared methane analyser (Sensor Europe GmbH, Erkrath, Germany) (Goel et al., 2008). Gas samples were then transferred into the inlet of an infrared methane analyser with a plastic syringe, which displays methane as a percentage of total gas. Methane production $(\mathrm{mL})$ was calculated as: Methane production $(\mathrm{mL})=$ total gas production $(\mathrm{mL}) \times$ percentage of methane $(\%)$

Data were analysed using the general linear model procedure of SPSS (1997, Chicago, Illinois, USA). Differences between reported means were determined using Duncan's multiple range tests with a 5\% level of probability. The results were presented as means and standard error of the means (SEM).

\section{Results and Discussion}

The chemical composition of silage raw materials is provided in Table 1. Citrus pulps had lower DM ratios, and greater OM than the maize plants. Although the low DM content of citrus by-products means they may be regarded as difficult ensiling products for anaerobic fermentation, their lower cellulose may compensate for energy deficits that result from lower DM ratios. On the other hand, citrus pulp generally shows low $\mathrm{pH}$ owing to the acidic structure (the presence of organic acids, mainly citric, malic, ascorbic and tartaric acid) (Falade et al., 2003). Therefore, the low pH is thought to have the potential to affect fermentation positively during the ensiling process, especially during the fermentation phase.

Table 1 Chemical composition of silage raw materials

\begin{tabular}{lrrrr}
\hline & Maize & Lemon pulp & Orange pulp & Tangerine pulp \\
\hline DM, g/kg & 263.2 & 237.9 & 201.3 & 214.5 \\
OM, g/kg DM & 899.8 & 952.8 & 964.5 & 961.6 \\
CP, g/kg DM & 62.6 & 75.6 & 46.3 & 48.1 \\
EE, g/kg DM & 18.4 & 28.4 & 8.1 & 9.8 \\
CF, g/kg DM & 261.5 & 115.2 & 68.3 & 75.3 \\
ADF, g/kg DM & 376.3 & 194.5 & 144.4 & 131.5 \\
NDF, g/kg DM & 590.5 & 216.1 & 155.1 & 148.4 \\
ADL, g/kg DM & 114.8 & 79.3 & 76.1 & 56.2 \\
HEM, g/kg DM & 214.2 & 21.6 & 10.7 & 16.9 \\
\hline
\end{tabular}

DM: dry matter, OM: organic matter, CP: crude protein, EE: ether extract, CF: crude fibre, NDF: neutral detergent fibre, ADF: acid detergent fibre, HEM: hemicellulose, ADL: acid detergent lignin

The chemical compositions of citrus pulp silage alone and with maize silage are given in Table 2. pH is one of the significant indicators of silage quality (Kiermeier \& Renner, 1963). The $\mathrm{pH}$ value of the silages (between 3.51 and 3.84) was close to the optimum silage pH value (between 3.8 and 4.2) (Coskun et al., 1998). The $\mathrm{pH}$ of the citrus pulp silage was not improved with the maize silage combination. But this is related mostly to DM, which varied between $158.7 \mathrm{~g} / \mathrm{kg}$ in the orange group and $369.7 \mathrm{~g} / \mathrm{kg}$ in the maize silage group and the values were lower than the expected DM values (between 250 and $350 \mathrm{~g} / \mathrm{kg}$ ) (Demirel \& Yıldız, 2000). Ergül et al. (2001) reported that the $\mathrm{pH}$ values of the silages prepared by adding 0, 15, 30 and $45 \%$ broiler litters to fruit juice and wet sugar beet pulp were between 4.1 and 4.2 . Similar to the present findings, Deniz et al. (2001) reported pH values of between 3.72 and 4.30 for the silages with $20 \%$ DM. In another study, Avcl et al. (2005) reported pH values of between 3.64 and 4.33 for silage containing 17\% DM and between 3.96 and 4.34 for silages containing 20\% DM. On the other hand, Ülger et al. (2015) reported a lower $\mathrm{pH}$ value (3.76) for sugar beet pulp as compared with the present results.

The DM of citrus pulp silage (between 158.7 and $212.2 \mathrm{~g} / \mathrm{kg}$ as fed) in the present study was in agreement with the DM that was previously reported as being between 123.7 and $149.2 \mathrm{~g} / \mathrm{kg}$ (Yalçınkaya et al., 2012; La Van Kinh \& Phuong, 1997). However, in the present study, combined citrus pulp and maize 
silage (50:50, on weight basis) had DM of between 230.9 and $289.4 \mathrm{~g} / \mathrm{kg}$, which is close to that of a highquality silage (Ergül, 1988). Thus, the present results indicate that the DM of citrus pulp should be increased to produce good silage. A desirable DM can be achieved by adding $50-60 \%$ maize silage to the citrus pulp (Gurbuz \& Kaplan, 2008). Combining citrus pulp with maize (50:50) in the current study increased the DM of the silage (between 230.9 and $289.4 \mathrm{~g} / \mathrm{kg}$ ), but it was still far from being high-quality silage. The DM of maize silage $(369.7 \mathrm{~g} / \mathrm{kg})$ of the present study was parallel with the findings of those authors who reported similar values of DM from maize silage (Idukut et al., 2009; Arslan \& Çakmakçı, 2011).

Organic matter levels of citrus pulp silages were close to each other and greater than the OM values of the maize silages. Citrus pulp thus reduced the OM of the combined silages. The greatest CP was observed in tangerine silage. Silage CP varied between 59.9 and $112.7 \mathrm{~g} / \mathrm{kg}$. The CP of citrus pulp silages was consistent with the findings of Bath et al. (1980). With regard to cellulose fractions, citrus pulp silages had lower ADF and NDF ratios than the maize silages, and citrus pulps generally had lower cellulose than the roughages. The ADF and NDF of the citrus pulp silages was increased with the maize silage combination, so citrus pulps are more suitable for inclusion in ruminant diets because of the ability of ruminants to ferment high fibre feeds in the rumen. In a previous study, the ADF of orange pulp silage and citrus pulp silage were reported as $220 \mathrm{~g} / \mathrm{kg}$ and $200 \mathrm{~g} / \mathrm{kg}$, respectively (Bath et al., 1980). The NDF and ADF of citrus lemon were consistent with the findings of Nazem et al. (2008), who reported the NDF and ADF of citrus lemon as 213 and $179 \mathrm{~g} / \mathrm{kg}$, respectively. However, the NDF and ADF of Citrus sinensis were considerably lower than those reported by Nazem et al. (2008). The number of studies about citrus pulp silages is limited. In a study on lemon varieties, the differences were found to be significant and the mean values were OM: 94.73\%, CP: 7.4\%, EE: 5.60\%, NDF: 20.05\% and ADF: 17.16\% (Özkan et al., 2017).

The nutritive values and fermentation metabolites of citrus pulp silage alone and with maize silage are given in Table 3. The total digestible nutrient (TDN) values varied between 654.6 (MS) and 857.6 (TPS) $\mathrm{g} / \mathrm{kg}$, and the differences in TDN values of the silages were found to be significant $(P<0.01)$. Citrus pulp silages generally had greater non-fibre carbohydrate (NFC) than single maize silage and combined $(P<0.01)$. Contrarily, fermentation metabolites of citrus pulp silages were less than the maize silages. While the lowest LA was observed in lemon and orange pulp silages, the greatest values were observed in maize silage $(P$ $<0.01$ ). (The values varied between 29.77 and $101.2 \mathrm{~g} / \mathrm{kg} \mathrm{DM}$.) The present LA productions were greater than the values reported in previous studies, probably because the proportion of material that remained in the pulp during the production of fruit pulps did not vary with the sugar. Citrus pulp generally generates more LA than sugar beet pulp, corn grain and sorghum grains (Cullen et al., 1986). In the previous studies, the mean values of LA, AA, PA and BA in orange silage were reported as $21.9 \mathrm{~g} / \mathrm{kg}, 29.8 \mathrm{~g} / \mathrm{kg}, 2.9 \mathrm{~g} / \mathrm{kg}$ and 0.5 g/kg, respectively (Martinez \& Fernandez, 1980; Lanza, 1984; Miron et al., 2001). 
Table 2 Chemical composition of citrus pulp silages alone and when combined with maize silage $50: 50$ on a weight basis

\begin{tabular}{|c|c|c|c|c|c|c|c|c|c|}
\hline \multirow{2}{*}{ Parameters } & \multicolumn{7}{|c|}{ Treatments } & \multirow{2}{*}{ SEM } & \multirow{2}{*}{$P$-value } \\
\hline & MS & LPS & OPS & TPS & LPS + MS & $\mathrm{OPS}+\mathrm{MS}$ & $\mathrm{TPS}+\mathrm{MS}$ & & \\
\hline $\mathrm{pH}$ & $3.84^{\mathrm{a}}$ & $3.63^{c}$ & $3.61^{c}$ & $3.73^{b}$ & $3.58^{\mathrm{cd}}$ & $3.51^{d}$ & $3.57^{\mathrm{cd}}$ & 00.3 & $<0.001$ \\
\hline $\mathrm{DM}, \mathrm{g} / \mathrm{kg}$ & $369.7^{\mathrm{a}}$ & $212.2^{\mathrm{e}}$ & $158.7^{f}$ & $162.3^{f}$ & $289.4^{\mathrm{b}}$ & $245.6^{c}$ & $230.9^{d}$ & 15.3 & $<0.001$ \\
\hline $\mathrm{OM}, \mathrm{g} / \mathrm{kg}$ & $901.3^{d}$ & $942.3^{\mathrm{a}}$ & $945.0^{\mathrm{a}}$ & $944.0^{a}$ & $908.7^{c}$ & $926.7^{b}$ & $912.3^{c}$ & 39.0 & $<0.001$ \\
\hline $\mathrm{CP}, \mathrm{g} / \mathrm{kg} \mathrm{DM}$ & $65.5^{\mathrm{e}}$ & $83.7^{\mathrm{C}}$ & $90.5^{b}$ & $112.7^{\mathrm{a}}$ & $78.0^{d}$ & $59.9^{f}$ & $84.0^{\mathrm{C}}$ & 3.6 & $<0.001$ \\
\hline EE, g/kg DM & $24.1^{\mathrm{abc}}$ & $17.7^{\mathrm{d}}$ & $16.4^{d}$ & $28.8^{a}$ & $26.3^{\mathrm{ab}}$ & $19.5^{\mathrm{cd}}$ & $20.6^{\mathrm{bcd}}$ & 1.1 & 0.003 \\
\hline $\mathrm{CF}, \mathrm{g} / \mathrm{kg} \mathrm{DM}$ & $246.4^{\mathrm{a}}$ & $104.4^{d}$ & $123.3^{d}$ & $117.2^{\mathrm{d}}$ & $195.2^{b}$ & $166.0^{\mathrm{C}}$ & $189.3^{b c}$ & 10.9 & $<0.001$ \\
\hline NDF, g/kg DM & $584.5^{\mathrm{a}}$ & $288.8^{d}$ & $287.6^{d}$ & $285.8^{d}$ & $435.0^{\mathrm{b}}$ & $411.2^{\mathrm{C}}$ & $448.0^{b}$ & 23.3 & $<0.001$ \\
\hline$A D F, g / k g ~ D M$ & $387.7^{\mathrm{a}}$ & $232.7^{\mathrm{e}}$ & $231.2^{\mathrm{e}}$ & $260.3^{d}$ & $333.7^{b}$ & $312.5^{c}$ & $323.0^{\mathrm{bc}}$ & 12.2 & $<0.001$ \\
\hline ADL, g/kg DM & 141.2 & 128.3 & 107.9 & 143.1 & 138.4 & 146.5 & 133.7 & 4.2 & 0.19 \\
\hline HEM, g/kg DM & $196.8^{\mathrm{a}}$ & $26.1^{d}$ & $16.4^{d}$ & $25.5^{d}$ & $101.3^{c}$ & $98.7^{\mathrm{c}}$ & $125.0^{\mathrm{b}}$ & 11.9 & $<0.001$ \\
\hline
\end{tabular}

MS: maize silage; LPS: lemon pulp silage; OPS: orange pulp silage; TPS: tangerine pulp silage; DM: dry matter, OM: organic matter, CP: crude protein, EE: ether extract, CF: crude fibre, NDF: neutral detergent fibre, ADF: acid detergent fibre, HEM: hemicellulose, ADL: acid detergent lignin SEM: pooled standard error of means

$a, b, c, d$ Within a row values with a common superscript are not different 
Table 3 Nutritive value and fermentation metabolites of citrus pulp silage alone and when combined with maize silage 50:50 on a weight basis

\begin{tabular}{|c|c|c|c|c|c|c|c|c|c|}
\hline \multirow{2}{*}{ Parameters } & \multicolumn{7}{|c|}{ Treatments } & \multirow{2}{*}{ SEM } & \multirow{2}{*}{$P$-value } \\
\hline & MS & LPS & OPS & TPS & LPS+MS & OPS+MS & TPS+MS & & \\
\hline TDN, g/kg DM & $654.6^{d}$ & $855.6^{a}$ & $856.4^{\mathrm{a}}$ & $857.6^{a}$ & $756.2^{c}$ & $772.4^{\mathrm{b}}$ & $747.3^{b}$ & 15.8 & $<0.001$ \\
\hline NFC, g/kg DM & $227.3^{\mathrm{e}}$ & $552.1^{a}$ & $550.5^{a}$ & $516.7^{\mathrm{b}}$ & $369.3^{\mathrm{d}}$ & $436.1^{c}$ & $359.8^{d}$ & 25.0 & $<0.001$ \\
\hline $\mathrm{TC}, \mathrm{g} / \mathrm{kg} \mathrm{DM}$ & $811.7^{c}$ & $840.9^{\mathrm{ab}}$ & $838.2^{b}$ & $802.5^{\mathrm{d}}$ & $804.3^{\mathrm{cd}}$ & $847.3^{a}$ & $807.8^{\mathrm{cd}}$ & 4.1 & $<0.001$ \\
\hline $\mathrm{FP}$ & $125.33^{a}$ & $102.22^{\mathrm{e}}$ & $92.20^{f}$ & $88.26^{f}$ & $119.80^{b}$ & $113.85^{c}$ & $108.52^{d}$ & 2.89 & $<0.001$ \\
\hline WSC, g/kg DM & $44.6^{b}$ & $56.5^{\mathrm{ab}}$ & $34.5^{\mathrm{b}}$ & $40.0^{b}$ & $81.2^{\mathrm{a}}$ & $55.4^{\mathrm{ab}}$ & $44.7^{b}$ & 4.2 & 0.03 \\
\hline LA, g/kg DM & $101.21^{a}$ & $37.51^{c}$ & $29.77^{C}$ & $73.77^{\mathrm{b}}$ & $41.64^{c}$ & $39.68^{c}$ & $51.64^{b}$ & 5.79 & 0.00 \\
\hline $\mathrm{AA}, \mathrm{g} / \mathrm{kg} \mathrm{DM}$ & $49.36^{a}$ & $29.48^{c}$ & $43.74^{\mathrm{ab}}$ & $38.47^{\mathrm{abc}}$ & $35.29^{\mathrm{bc}}$ & $32.82^{\mathrm{bc}}$ & $28.83^{c}$ & 2.03 & 0.03 \\
\hline$P A, g / k g ~ D M$ & $28.27^{\mathrm{ab}}$ & $33.32^{\mathrm{a}}$ & $20.84^{b c}$ & $20.11^{\mathrm{bc}}$ & $19.49^{b c}$ & $13.77^{\mathrm{c}}$ & $14.99^{c}$ & 1.77 & 0.01 \\
\hline $\mathrm{BA}, \mathrm{g} / \mathrm{kg} \mathrm{DM}$ & ND & 0.61 & ND & ND & ND & ND & ND & 0.08 & 0.24 \\
\hline LA/AA & $2.11^{a}$ & $1.43^{\mathrm{abc}}$ & $1.95^{\mathrm{bc}}$ & $0.69^{c}$ & $1.19^{b c}$ & $1.83^{\mathrm{ab}}$ & $1.18^{\mathrm{bc}}$ & 0.13 & 0.03 \\
\hline
\end{tabular}

MS: maize silage; LPS: lemon pulp silage; OPS: orange pulp silage; TPS: tangerine pulp silage TDN: total digestible nutrients; OM: organic matter; NFC: non-fibre carbohydrates; TC: total carbohydrates; FP: Fleig point; WCS: water soluble carbohydrate; LA: lactic acid; AA: acetic acid; PA: propionic acid; BA: butyric acid; ND: not detected; SEM: pooled standard error of means;

$a, b, c, d$ Within a row values with a common superscript are not different 
The in vitro gas and methane production of citrus pulp silage alone and with maize silage are given in Table 4. The TG values of silage materials varied between $65.33 \mathrm{~mL}(\mathrm{MS})$ and $77 \mathrm{~mL}$ (OPS) and the differences in TG values of the silages were not found to be significant $(P=0.07)$. The 24-hour methane production levels of the silage groups ranged from 9.7 to 12.38 and the lowest and highest values for $\mathrm{ME}$ were determined as 11.08 (MS) and 12.67 (OPS) MJ/kg DM. The greatest net energy lactation (NEL) (8.49 $\mathrm{MJ} / \mathrm{kg} \mathrm{DM}$ ) was obtained from the orange group and the lowest value $(7.15 \mathrm{MJ} / \mathrm{kg} \mathrm{DM})$ was obtained from the maize group. The OMD values varied between $76.96 \%$ (MS) and $87.33 \%$ (OPS). In a study carried out with different types of lemon pulp silage, total gas production was reported as between 68.7 and $77.6 \mathrm{~mL}$. Methane production ranged from 10.1 to $13.6 \mathrm{~mL}$. ME values ranged from 12.0 to $13.2 \mathrm{MJ} / \mathrm{kg}$, and OMD values ranged from 82.7 to $91.5 \%$ (Özkan et al., 2017).

Table 4 In vitro gas and methane production of citrus pulp silage alone and with maize silage

\begin{tabular}{|c|c|c|c|c|c|c|c|c|c|}
\hline \multirow{2}{*}{ Parameters } & \multicolumn{7}{|c|}{ Treatments } & \multirow{2}{*}{ SEM } & \multirow{2}{*}{$\mathrm{P}$} \\
\hline & MS & LPS & OPS & TPS & LPS+MS & OPS+MS & TPS+MS & & \\
\hline $\mathrm{TG}, \mathrm{mL}$ & 65.33 & 74.00 & 77.00 & 74.67 & 68.00 & 66.67 & 68.00 & 1.31 & 0.07 \\
\hline $\mathrm{CH}_{4}, \mathrm{~mL}$ & 10.79 & 12.38 & 11.73 & 11.77 & 9.70 & 11.52 & 10.63 & 0.27 & 0.12 \\
\hline $\mathrm{CH}_{4}, \%$ & 16.53 & 16.78 & 15.24 & 15.77 & 14.31 & 17.26 & 15.65 & 0.32 & 0.19 \\
\hline $\mathrm{ME}, \mathrm{MJ} / \mathrm{kg} \mathrm{DM}$ & 11.08 & 12.26 & 12.67 & 12.35 & 11.45 & 11.27 & 11.45 & 0.18 & 0.07 \\
\hline NEL, MJ/kg DM & 7.15 & 8.14 & 8.49 & 8.22 & 7.45 & 7.30 & 7.45 & 0.15 & 0.07 \\
\hline OMD, $\%$ & 76.96 & 84.66 & 87.33 & 85.26 & 79.33 & 78.15 & 79.33 & 1.17 & 0.07 \\
\hline
\end{tabular}

MS: maize silage; LPS: lemon pulp silage; OPS: orange pulp silage; TPS: tangerine pulp silage; LPS+MS: lemon pulp silage+maize silage (50/50 by weight basis); OPS+MS: orange pulp silage+maize silage; TPS+MS: tangerine pulp silage+maize silage; SEM: pooled standard error of means; P: probability; ${ }^{*} P<0.05 ;{ }^{*}: P<0.01$; NS: not significant; TG: total gas production; ME :metabolizable energy; NEL: net energy lactation; OMD: organic matter digestibility

a, b, c, d: Values with different superscript in a line differ significantly between treatment groups

\section{Conclusion}

By-products of the fruit juice industry can be used as silage materials in spite of their high moisture content. The citrus pulp silages generally had good silage quality in terms of OM, OMD and ME. However, the DM content of the citrus pulps should be increased with the addition of maize. The nutrient content (especially TDN and NFC) of maize silage may also increase silage quality when ensiled with citrus pulps. Thus, it is recommended that citrus pulp be combined with chopped combined with maize to control the freshness and management of these silages.

\section{Acknowledgements}

This study was supported by Scientific Research Fund of Erciyes University (Project number: FBA-2016-6843).

\section{References}

Akyildiz. A.R., 1986. Feed Science and Technology. Agricultural Faculty Publications, Ankara University, Publication no 895. Ankara, Turkey, 974.

AOAC, 1996. Official Methods of analysis of AOAC International. 16th edition. Gaithersburg, MD, USA.

AOAC, 2000. Official Methods of analysis of AOAC International. 17th edition. Gaithersburg, MD, USA.

Arslan, M. \& Çakmakçı, S., 2011. Comparison of corn (Zea mays) and sorghum (Sorghum bicolor) silages mixed with different plants. Mediterr. Agric. Sci. 24, 47-53.

Ashbell, G., 1994. Basic principles of preservation of forage, by-product and residues as silage or hay. ARO. The Volcani Centre, Bet-Dagan, Israel.

Avcı, M., Akdeniz, H. \& Deniz, S., 2005. Değişik katkılarla hazırlanan yaş şeker pancarı posası silajlarının kalitesinin belirlenmesi. III. Ulusal Hayvan Besleme Kongresi, 7-10 Eylül, Adana.

Barker, S.B. \& Summerson, W.H., 1941. The colorimetric determination of lactic acid in biological material. J. Biol. Chem. $138,535-554$.

Bath, D.L., Dunbar, J.R., King, J.M., Berry, S.L., Leonard, R.O. \& Olbrich, S.E., 1980. By-products and unusual feedstuffs in livestock rations. Western Regional Extension Publication No. 39. USDA-ARS, Washington, DC, USA. 
Canbolat, Ö., Kamalak, A. \& Kara, H., 2014. The effects of urea supplementation on pomegranate pulp (Punicagranatum L.) silage fermentation, aerobic stability and in vitro gas production. Ankara Üni. Vet. Fak. Derg. 61, 217-223.

Chandler, P., 1990. Energy prediction of feeds by forage testing explorer. Feedstuff. 1,12.

Coskun, B., Seker, E. \& İnal, F., 1998. Yemler ve Teknolojisi, Selçuk Üniversitesi Veteriner Fakültesi Yayın Ünitesi, Konya

Cullen, A.J., Harmon, D.L. \& Nagaraja, T.G., 1986. In vitro fermentation of sugars, grains, and by-product feeds in relation to initiation of ruminal lactate Production. J. Dairy Sci. 69, 2616-2621.

Demirel, M. \& Yıldız, S., 2000. Hamur olum döneminde biçilen arpa hasılına kimi katkı maddeleri katılmasının silaj kalitesi ve rumende ham besin maddelerinin yıkılımı üzerine etkisi. International Animal Nutrition Congress, 4-6 Eylül, Isparta, pp. 270-276.

Deniz, S., Demirel, M., Tuncer, Ş.D., Kaplan, O. \& Aksu, T., 2001. Değişik şekillerde üretilen şeker pancarı posası silajının süt ineği ve kuzu rasyonlarında kullanılma olanakları. 1. Kaliteli şeker pancarı posası silajının elde edilmesi. Turkish J. Vet. Anim. Sci. 25, 1015-1020.

Dubois, M., Gilles, K.A., Hamilton, J.K., Rebers, P.A. \& Smith, F., 1956. Calorimetric method for determination of sugars and related substances. Anal. Chem. 28, 350-356.

Duru, A.A. \& Kaya, Ş., 2015. Zeytin Posası Silajının Hayvan Beslemede Kullanım Olanakları. M. Kemal Üni. Zir. Fak. Derg. 20.

Ergül, M., 1988. Knowledge and technology of feed. Aegean Univ. Agriculture Fac. Publishing, Izmir, pp. 487, 318.

Ergül, M., Alçiçek, A., Ayhan, V., Kılıç, A., Özkul, H., Basmacıoğlu, H. \& Karaayvaz, K., 2001. Kanatlı altığının bazı yem kaynakları ile silolanma olanakları ve yem değeri. 1. Pancar posasının broiler altığı ile silolanma olanakları ve yem değeri. Ege Üni. Zir. Fak. Derg. 38, 1018- 8851.

Falade, O.S., Sowunmi, O.R., Oladipo, A., Tubosun, A. \& Adewusi, S.R., 2003. The level of organic acids in some Nigerian fruits and their effect on mineral availability in composite diets. Pakistan J. Nut. 2, 82-88.

Filya, İ., Hanoğlu, H., Canbolat, Ö. \& Sucu, E., 2006. Kurutulmuş pirinanın yem değeri ve kuzu besisinde kullanılma olanakları üzerinde araştırmalar. 1. Yem Değerinin in situ Yöntemle belirlenmesi. Uludağ Üni. Zir. Fak. Derg. 20, $1-12$.

Fussell, R.J. \& McCalley, D.V., 1987. Determination of volatile fatty acids (C2-C5) and lactic acid in silage by gas chromatography. Analyst. 112(9), 1213-1216.

Goel, G., Makkar, H.P. \& Becker, K., 2008. Effects of Sesbaniasesban and Carduuspycnocephalus leaves and Fenugreek (Trigonellafoenum-graecum L.) seeds and their extracts on partitioning of nutrients from roughage-and concentrate-based feeds to methane. Anim. Feed Sci. Tech. 147, 72-89.

Gurbuz, Y. \& Kaplan, M., 2008. Chemical composition, organic matter digestibility, in vitro gas production characteristics and ensiling of sugar beet leaves as alternative feed resource. J. Anim. Vet. Adv. 7,1568-1574.

Idukut, L., Arikan, B.A., Kaplan, M., Guven, I., Atalay, A.I. \& Kamalak, A., 2009. Potential nutritive value of sweet corn as a silage crop with or without corn ear. J. Anim. Vet. Adv. 8, 734-741.

Kale, P.N. \& Adsule, P.G., 1995. Citrus. In: D.K Salunkhe \& S.S. Kadam (eds). Handbook of fruit science and technology: Production, composition, storage and processing. CRC press, pp. 39-65.

Kiermeier, F. \& Renner, E., 1963. Der pH wert aiskriterium der verwendbarkeit von silage für die milchvieh Fütterung. Das Wirtschaftseiq. Futterq. 1, 106-113.

Koc, F., 2019 Silaj inokulantları kullanarak yapılan araştırmaların meta analitik değerlendirilmesi. Erciyes Tar. Hayvan Bilim. Derg. 2, 21-34.

La Van Kinh, V.V.D. \& Phuong, D.D., 1997. Chemical composition of cashew apple and cashew apple waste ensiled with poultry litter. Livest. Res. Rural Develop. 9.

Lanza, A., 1984. Dried citrus pulp in animal feeding. In: J. Holl'o (ed). Proceedings of the International Symposium on Food Industries and the Environment. Budapest, Hungary. Elsevier, New York, NY, USA, pp. 189-198.

Martinez, P., Fernandez, C., 1980. Composition of citrus pulp. Anim. Feed Sci. Technol. 5(1), 1-10.

Menke, K.H., Raab, L., Salewski, A., Steingass, H., Fritz, D. \& Schneider, W., 1979. The estimation of the digestibility and metabolizable energy content of ruminant feeding stuffs from the gas production when they are incubated with rumen liquor in vitro. J. Agric. Sci. 93, 217-222.

Menke, K.H. \& Steingass, H., 1988. Estimation of the energetic feed value obtained from chemical analysis and in vitro gas production using rumen fluid. Anim. Res. Devel. 28,7-55.

Miron, J., Yosef, E. \& Ben-Ghedalia, D., 2001. Composition and in vitro digestibility of monosaccharide constituents of selected by product feeds. J. Agric. Food Chem. 49, 2322-2326.

Nazem, K., Rozbehan, Y. \& Shodjaosadati, S.A., 2008. The nutritive value of citrus pulp (lemon and orange) treated with Neurospora sitophila. J. Sci. Tech. Agri. Nat. Res. 12, 495-505.

Özkan, Ç.Ö., Kaya E., Ülger, İ., Güven, İ. \& Kamalak, A., 2017. Effect of species on nutritive value and methane production of citrus pulps for ruminants. Hayv.Üret.58, 8-12.

Sniffen, C.J., O'Connor, J.D., Van Soest, P.J., Fox, D.G. \& Russell, J.B., 1992. A net carbohydrate and protein system for evaluating cattle diets: II. Carbohydrate and protein availability. J. Anim. Sci. 70, 3562-3577.

TÜiK, 2017. Meyveler, İçecek ve Baharat Bitkileri- Turunçgiller. http://www.tuik.gov.tr/PreTablo.do?alt_id=1001 Accession date: 17.10 .2019 .

Ülger, İ., Kaliber, M., Buyukkilic Beyzi, S. \& Konca, Y., 2015. Yaş şeker pancarı posasının bazı meyve posaları ile silolanmasının silaj kalite özellikleri, enerji değerleri ve organic madde sindirilebilirlikleri üzerine etkisi. Alınteri Zirai Bil. Derg. 29,19-25. 
Ülger, İ., Kaliber, M., Ayaşan, T. \& Küçük, O., 2018a. Chemical composition, organic matter digestibility and energy content of apple pomace silage and its combination with corn plant, sugar beet pulp and pumpkin pulp. S. Afr. J. Anim Sci. 48, 497-503.

Ülger, İ., Kaplan, M., Atasagun, B., Kardeş, Y. M., Doran, T. \& Kamalak, A., 2018b. Vejetasyon Döneminin Erciyes Korungasının (Onobryhis Argaea) Yem Özellikleri Üzerine Etkisi. Erciyes Tar. Hayvan Bilim. Derg. 38-49.

USDA/FAS, 2003. United States Department of Agriculture / Foreign Agricultural Service, Situation and Outlook for Citrus. Horticultural and Tropical Products Division, Washington, DC, USA.

Van Soest, P.H., Robertson, J.B. \& Lewis, B., 1991. Methods for dietary fiber, neutral detergent fiber, and nonstarch polysaccharides in relation to animal nutrition. J. Dairy Sci. 74, 3583-3597.

Velioglu, Y.S., Mazza, G., Gao, L. \& Oomah, B.D., 1998. Antioxidant activity and total phenolics in selected fruits, vegetables, and grain products. J. Agri. Food Chem. 46, 4113-4117.

Weiss, W.P., Conrad, H.R. \& Pierre, N.R., 1992. A theoretically-based model for predicting total digestible nutrient values of forages and concentrates. Anim. Feed. Sci. Technol. 39,95-110.

Yalçınkaya, M.Y., Baytok, E. \& Yörük, M.A., 2012. Değişik meyve posası silajlarının bazı fiziksel ve kimyasal özellikleri. Erciyes Üniv. Vet. Fak. Derg. 9, 95-106. 